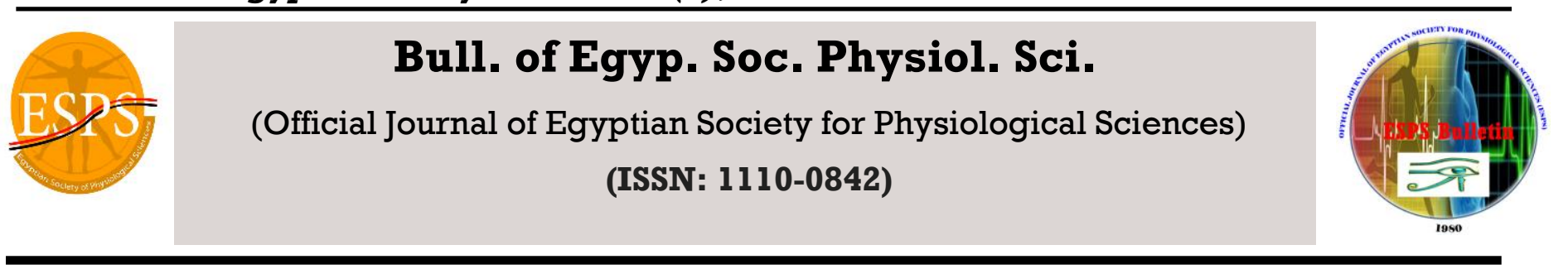

\title{
The Effect of Resveratrol on Insulin Resistance, Metabolic Syndrome and Hepatic Oxidative Stress in Fructose- Fed Rats
}

\author{
Ahmed A. Abdalfattah \\ Department of Physiology, Faculty of Medicine, Tanta University, Egypt
}

Received : Feb 10, 2014

Accepted: March 14, 2014

Available online: April 7, 2014

\section{Keywords}

Resveratrol

High fructose diet

Metabolic syndrome

Hepatic oxidative stress

\section{Abstract}

Background/Aim: Metabolic syndrome and oxidative stress are common complications of type 2 diabetes mellitus. The aim of this work was to study the effect of resveratrol, a widely used nutritional supplement on insulin sensitivity, some metabolic parameters and hepatic oxidative stress in high fructose- fed rats. Material \& methods: Male Wister rats (180-200g) were divided into 3 groups 10 per each. G1: Control group was fed 65\% corn starch diet. G2: Fructose-fed insulin resistant group (HFD) was fed 65\% fructose diet. G3: (HFD + Resveratrol) was fed with $65 \%$ fructose along with a single dose of $10 \mathrm{mg} / \mathrm{kg} /$ day of resveratrol orally through intra gastric tube for a period of 8 weeks. Results: At the end of the feeding schedule, HFD group had significant hyperglycemia, hyperinsulinemia and insulin resistance as evident by HOMA IR. There were significant increase in triglyceride and nitric oxide levels as well as in hepatic ThioBabituric Acid Reactive Substance (TBARS) and significant decrease in vitamin C in HFD group compared with control group. Administration of resveratrol significantly improved the altered metabolic parameters, hepatic oxidative stress parameters and significantly reduced inflammatory markers (Monocyte Chemoattractant Protein -1(MCP-1), Tumor Necrosis Factor $\alpha$ $(\mathrm{TNF} \alpha)$ and Regulated on Activation Normal T cells Expressed and Secreted (RANTES).

Conclusion: Resveratrol supplementation might attenuate the insulin resistance, hepatic oxidative stress state and inflammatory state in metabolic syndrome.

Corresponding author: Ahmed Abdalfattah, Faculty of Medicine, Tanta University, Egypt.

E-mail address: pacemaker107@gmail.com 


\section{INTRODUCTION}

Researches in humans and experimental animal models have focused on the association between obesity, insulin resistance, dyslipidemia and hypertension, and have been closely linked to the development of diabetes and cardiovascular disease. ${ }^{1}$ Diabetes Mellitus (DM) is a common, serious, chronic, and currently incurable metabolic disorder of worldwide significance. The disease is known to be associated with a high risk of micro vascular and macro vascular complications and very often leads to premature death. Despite the availability of many anti diabetic agents and pharmacotherapies, targeting cardiovascular risk factors, the morbidity, mortality and economic consequences of DM is still a great burden to patients, society, health care systems and the economy ${ }^{2}$.

Many pharmacologic and nonpharmacologic interventions have been developed based on current understanding of the pathophysiology of type 2 diabetes (DM2). However, the existing treatments have limitations either because of their side effects, particularly weight gain and hypoglycemia or contraindications that limit their use. Furthermore, none of the current therapies have a significant impact on the associated risk factors. Therefore, there is a need, for new therapies that may improve not only hypoglycemic effect but also the associated problems. Resveratrol (3,5,4'trihydroxystilbene) belongs to the large group of polyphenols found in different plant species. The richest natural source of resveratrol is Polygonumcuspidatum a plant root extract of which have been used in oriental folk medicine. Considerable amounts of resveratrol were also found, among others, in peanuts, groundnuts, Itadori tee, grapevines and red wine ${ }^{3,4}$. Apart from natural sources, this compound is recently available in tablets and is recommended as a dietary supplement. The interest in resveratrol substantially increased and its broad biological activity at the cellular level has been previously demonstrated. Resveratrol cardio protective effects had been demonstrated before ${ }^{\mathbf{5 , 6}}$, its beneficial role in $\operatorname{cancer}^{7,8}$ and its antiinflammatory \& antioxidant properties ${ }^{9}$. Moreover, resveratrol, as a component of red wine, is thought to be responsible for the French paradox i.e. low mortality due to coronary heart disease as a result of moderate consumption of red wine ${ }^{10}$.

Data reinforced this theory and indicated that resveratrol play a crucial role in cardiovascular protection provided by grapes and wines ${ }^{11}$. Although it is known that in humans resveratrol is rapidly absorbed after its oral administration and is detected in both plasma and urine, data concerning the potential beneficial effects of the pure compound in humans are still very 
limited $^{12}$. However, more researches are needed on the anti-diabetic activity of resveratrol along with its diverse biological action that directly or indirectly reduce diabetic complications in fructose fed animals. Consumption of fructose in the form of high fructose corn syrup (HFCS) is increasing every day. Long term fructose intake induces diabetes along with insulin resistance and metabolic syndrome in human as well as experimental animals ${ }^{13}$.The aim of this work is to study the effect of resveratrol, a widely used nutritional supplement on insulin sensitivity, some metabolic parameters, hepatic inflammatory markers and oxidative stress in high fructose- fed rats.

\section{MATERIALS AND METHODS}

Experimental animals: All animal experiments were undertaken with the approval of Ethical Animal Research Committee of Tanta University. Thirty male Wister rats weighing (180-200 g) were purchased from the Faculty of Science (Tanta University). The animals were housed at temperature $22 \pm 2{ }^{\circ} \mathrm{C}$ and $12 \mathrm{~h}$ dark/light cycle throughout the study. Animals were randomly divided into three groups 10 per each. G1: Control group was fed 65\% corn starch diet, G2: High Fructose-Fed insulin resistant group (HFD) was fed 65\% fructose diet and G3: (HFD +
Resveratrol) was fed with $65 \%$ fructose along with a single dose of $10 \mathrm{mg} / \mathrm{kg} /$ day of resveratrol (Sigma) orally through intra gastric tube for a period of 8 weeks. ${ }^{14}$ The composition of both diets is determined according to Perter et al. ${ }^{15}$

Body weight and food intake: Changes in body weight and food intake patterns of rats in all groups were noted throughout the experimental period. The weight of each rat was recorded on day 0 and at weekly intervals throughout the course of the study. The quantity of food consumed by each group was recorded, to facilitate measures of food intake, rats were housed conventionally in individual stainless steel hanging wiremesh cages, with food and tap water provided ad libitum. On arrival, all rats were placed immediately into their respective experimental conditions and allowed access to a pre weighted amount of food so that the first intake measures could be obtained the next day ${ }^{15}$ and the food consumption per rat was calculated for all groups.

\section{Biochemical assay:}

After 8 weeks of feeding and drug administration, rats were fasted overnight, animals were sacrificed by exsanguination. Blood was collected by cardiac puncture, serum was separated by centrifugation at $4000 \mathrm{rpm}\left(4^{\circ} \mathrm{C}\right)$ for $15 \mathrm{~min}$ and serum was frozen at $-70^{\circ} \mathrm{C}$ in aliquots until biochemical analysis were performed. Blood 
glucose was measured using glucometer (Bionime One Touch; Blood Glucose Monitoring System, China) ${ }^{15}$.

Serum insulin was measured by using commercially specific ELIZA kit (Mercodia, USA) ${ }^{13}$.

Serum triglycerides: were measured by triglyceride kits (Siemens, India) using an auto blood analyzer (Bayer Corp., USA) ${ }^{15}$.

Intraperitoneal glucose tolerance test (IPGTT) was performed according to the method described by Padiya et al., ${ }^{13}$ Rats from all three groups were injected intraperitoneally with a freshly prepared glucose load of $2 \mathrm{~g} / \mathrm{kg}$ of body weight. A drop of blood was withdrawn from tail vein by a small puncture using needle to analyze blood glucose using glucometer at $(0 \mathrm{~min})$ and at 5, 15, 30, 60 and 120 min after insertion of glucose load.

Nitric oxide (NO) was determined by a commercially available kit (Sigma, USA) according to the method described by Sojitraet al.,. ${ }^{16}$

ThioBarbituric Acid Reactive Substance (TBARS): Liver tissues were collected and stored at $-70{ }^{\circ} \mathrm{C}$ for further biochemical evaluation. Each liver tissue was homogenized with 20 times volume of liver weight (100 mg tissue in $2.0 \mathrm{~mL}$ buffer) in ice cold $0.05 \mathrm{M}$ potassium phosphate buffer $(\mathrm{pH}$ 7.4) and treated separately for different measurement. Liver homogenate was used for the estimation of ThioBarbituric Acid Reactive Substance (TBARS) a marker of lipid peroxidations ${ }^{17}$.

Glutathione measurement: The remaining volume of homogenate was put for centrifugation at $15,000 \times \mathrm{g}$ for $30 \mathrm{~min}$ at 4 ${ }^{\circ} \mathrm{C}$. The supernatant was collected and used for the estimation of reduced glutathione $(\mathrm{GSH})^{18}$ as a level of endogenous antioxidant.

Serum vitamin $C$ was measured according to the method described by Roe and Kuether, ${ }^{19}$. All of the compounds used for the estimation of different biochemical parameters were obtained from Sigma, USA.

Serum chemokines (MCP -1, TNF $\alpha$ and RANTES) were measured according to the method described by Ilhan et al ${ }^{1}$.

Histopathology: liver tissues were fixed in $10 \%$ neutral buffered formalin for $48 \mathrm{~h}$. The fixed tissue was mounted on the section stage with the appropriate adhesive, $10 \mu \mathrm{m}$ thin sections were cut on Oscillating Tissue Slicer and then sections were stained with hematoxylin and eosin. Liver specimens were exminaed blindly by expert pathologists.

Statistical analysis: All values were expressed as mean \pm SD. SPSS version 16.0 was used for statistical analysis. Data were statistically analyzed using one-way 
ANOVA for multiple group comparison. Significance was set at $\mathrm{p} \leq 0.05$.

\section{RESULTS}

The average food intake (g/d) and body weight gain:

The average food intake $(\mathrm{g} / \mathrm{d})$ showed insignificant variation among the study groups (Fig.1). As regard the body weight gain during the experimental period, there was no significant change after 8 weeks of fructose feeding in HFD group compared with the control group (Fig.2). However,

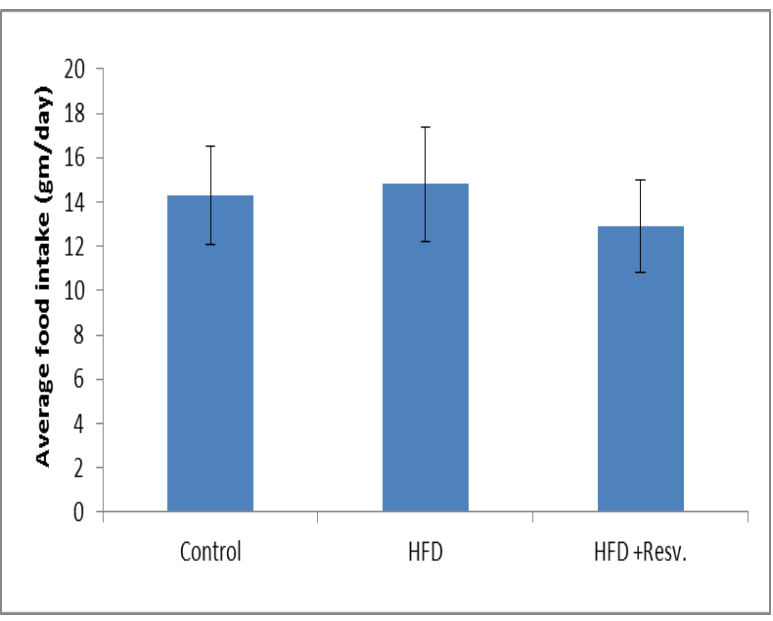

Fig. (1): Average food intake gram/day

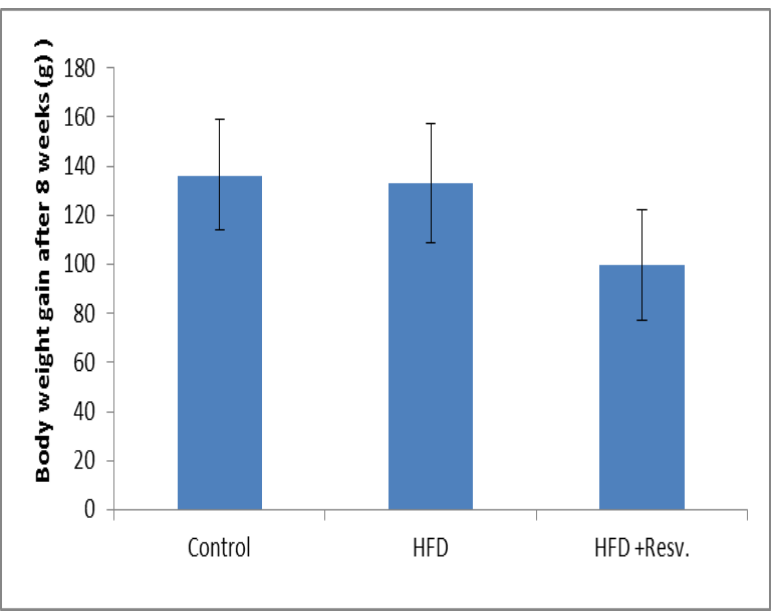

Fig. (2) Body weight gain after 8 weeks

* Means significant change VS. HFD group,

$\uparrow$ Means significant change VS. control group resveratrol administration reduced significantly body weight compared with the control and HFD groups $(\mathrm{P}<0.05)$.

Blood glucose levels and intraperitoneal glucose tolerance test (IGTT): After 8 weeks of feeding, rats from HFD group showed a significant increase in blood glucose level compared with the control group $(\mathrm{P}<0.001)$. Administration of resveratrol reduced significantly the blood glucose level. There was no significant change between the control and resveratrol administered group. Intraperitoneal glucose load led to marked increase in blood glucose level in HFD group at 5, 15, and 30 minutes compared with the control group. However, resveratrol administration causes insignificant change as compared to 0 basal level (Fig.3)

Serum insulin, HOMA-IR and triglyceride levels: In fructose- fed rats group, hyper insulinaemia was developed. Insulin level was significantly higher in HFD group compared with control group $(\mathrm{P}<0.001)$. Resveratrol administration reduced significantly serum insulin level compared with HFD group. There was significant difference between control and resveratrol treated groups $(\mathrm{P}<0.05)$ (table1). 


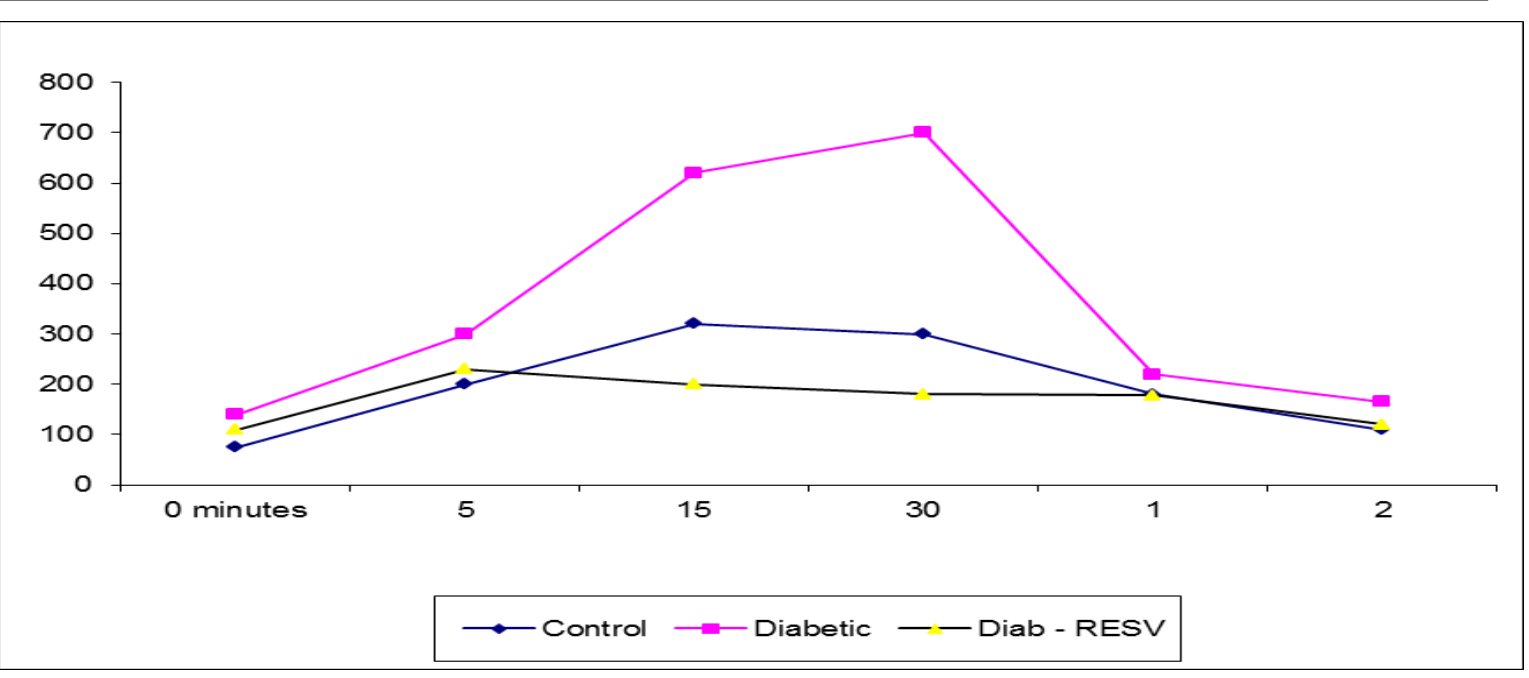

Fig. (3): Effect of resveratrol on intrapertoneal glucose tolerance test

HOMA-IR values were significantly different among the three studied groups. As regard serum triglyceride, HFD group showed significant increase $(\mathrm{P}<0.001)$ compared with the control group. Resveratrol administration reduced significantly the elevated triglyceride level caused by high fructose $\operatorname{diet}(\mathrm{P}<0.001)$. No significant change was observed between resveratrol treated and control groups.

\section{Serum Nitric Oxide $\mu \mathrm{mol} / \mathrm{L}$ (NO):}

Significant increase in serum nitric oxide was observed in HFD group compared with control group $(\mathrm{P}<0.001) . \quad$ Resveratrol administration reduced NO level significantly $(\mathrm{P}<0.001)$. Significant change was observed when comparing resveratrol treated and control group $(\mathrm{P}<0.05)($ table 2$)$.

Vitamin C (Vit.C) mg/dl: Vitamin C, an important antioxidant to maintain redox balance in different tissues. Vit. C levels were reduced significantly in HFD group compared with control group $(\mathrm{P}<0.001)$.

However, chronic resveratrol administration significantly increased hepatic vitamin $\mathrm{C}$ compared to HFD group $(\mathrm{P}<0.001)$. Significant change was observed when comparing resveratrol treated and control groups (table 2).

Tab (1): Metabolic parameters characteristics of groups:

\begin{tabular}{|l|c|c|c|c|}
\hline & $\begin{array}{c}\text { Control } \\
\text { group }\end{array}$ & $\begin{array}{c}\text { HFD } \\
\text { group }\end{array}$ & $\begin{array}{c}\text { HFD + } \\
\text { Resv. } \\
\text { group }\end{array}$ & f. test \\
\hline $\begin{array}{l}\text { Insulin m } \\
\text { IU/ml }\end{array}$ & $12.8 \pm 6.1$ & $46.7 \pm 6.21$ & $22.2 \pm 5.2$ & 12.633 \\
\hline $\begin{array}{l}\text { Glucose } \\
\text { (mg/dI) }\end{array}$ & $76.4 \pm 6.1$ & $142 \pm 22.7$ & $79.3 \pm 10.3$ & 8.336 \\
\hline HOMA-IR & $1.57 \pm 0.71$ & $6.2 \pm$ & $2.71 \pm 0.61$ & 5.336 \\
& $120.8 \pm 9.4$ & $203.3 \pm$ & $125.8 \pm 11$. & 6.366 \\
\hline $\begin{array}{l}\text { Triglyceride } \\
\text { (mg/dl) }\end{array}$ & & 36.7 & 9 & \\
\hline
\end{tabular}

ThioBabituric Acid Reactive Substance

TBARS n mol /gm weight tissue: Hepatic

TBARS levels were significantly increased in HFD group compared with control group $(\mathrm{P}<0.05)$. Resveratrol administration showed significant reduction of the increased TBARS levels $(\mathrm{P}<0.05)$. Significant change 
was observed when comparing resveratrol treated group to control group (table 2).

Table (2): Serum nitric oxide ( $\mu \mathrm{mol} / \mathrm{L}$ ), vitamin $\mathrm{C}$, and liver reduced GSH and TBARS in all the studied groups

\begin{tabular}{|l|c|c|c|c|}
\hline & $\begin{array}{c}\text { Control } \\
\text { group }\end{array}$ & $\begin{array}{c}\text { HFD } \\
\text { group }\end{array}$ & $\begin{array}{c}\text { HFD + } \\
\text { Resv. } \\
\text { group }\end{array}$ & f. test \\
\hline $\begin{array}{l}\text { Serum Nitric } \\
\text { Oxide } \\
\text { ( } \boldsymbol{m m o l} / \mathbf{L})\end{array}$ & $30.9 \pm$ & $72.8 \pm$ & $39.2 \pm 4.5$ & 81.793 \\
\hline $\begin{array}{l}\text { Vitamin C } \\
\text { mg/dl }\end{array}$ & 8.1 & 11.5 & & \\
\hline $\begin{array}{l}\text { TBARS } \\
\text { nmol/gm } \\
\text { tissue weight }\end{array}$ & $0.20 \pm 0.03$ & $25.1 \pm$ & $96.9 \pm$ & 97.940 \\
\hline $\begin{array}{l}\text { GSH ug/gm } \\
\text { tissue wt }\end{array}$ & $0.20 \pm 0.03$ & 0.28 & $0.19 \pm$ & 56.945 \\
& & \pm 0.04 & 0.03 & \\
\hline
\end{tabular}

Hepatic GSH $\boldsymbol{\mu g}$ /gm. wt. tissue: Hepatic GSH level showed no significant change when comparing HFD group to control group. Administration of resveratrol significantly increased hepatic GSH level compared to HFD and control groups $(\mathrm{P}<0.001)($ table 2).

Table (3): Serum chemokines levels (MCP-1, RANTES levels divided on 10 and TNF- $\alpha$ ).

\begin{tabular}{|l|c|c|c|c|}
\hline & $\begin{array}{c}\text { Control } \\
\text { group }\end{array}$ & $\begin{array}{c}\text { HFD } \\
\text { group }\end{array}$ & $\begin{array}{c}\text { HFD + } \\
\text { Resv. } \\
\text { group }\end{array}$ & f. test \\
\hline MCP-1 (pg/ml) & $46.2 \pm$ & $71.1 \pm$ & $47 \pm$ & 5.669 \\
& 4.2 & 3.14 & 8.9 & \\
\hline RANTES & $74.3 \pm$ & $176.95 \pm$ & $83.65 \pm$ & 15.336 \\
(pg/ml)Divided & 2.53 & 42.1 & 2.27 & \\
on 10 & & & & \\
\hline TNF- $\boldsymbol{\alpha}$ (pg/ml) & $35.4 \pm$ & $54.9 \pm$ & $40 \pm$ & 6.335 \\
& 4.62 & 18.1 & 5.1 & \\
\hline
\end{tabular}

MCP-1, RANTES levels and TNF- $\alpha$ :

Serum level of MCP-1 was significantly higher in HFD group compared with control group $(\mathrm{P}<0.001)$. Resveratrol administration reduced it significantly $(\mathrm{P}<0.001)$. No significant change was observed between resveratrol treated and control group. RANTES level showed significant elevation in HFD group as compared with control group $(\mathrm{P}<0.001)$ and resveratrol administration reduced the elevated RANTES significantly $\quad(\mathrm{P}<0.001)$. Significant change was observed when comparing the resveratrol treated and control groups. The same was observed as regard TNF- $\alpha$ as it showed significant increase in HFD group compared with control group $(\mathrm{P}<0.05)$ Resveratrol administration reduced it significantly $(\mathrm{P}<0.05)$. Significant change was observed when comparing resveratrol treated group and control group (table 3).

\section{Histopathology:}

Liver sections showed normal liver architecture ( central vein with endothelial lining, hepatocytes with normal nuclei and sinusoidal spaces with Kupffer cells (K) ) in control group (Fig. 4 A\&B). While, liver obtained from HFD group showed distended central vein, disarrangement of hepatocytes, some nuclei are pycnotic and there are leucocytic infiltrations into the vein (Fig. 4 C\&D). On the other hand, resveratrol treated animals showed normal histology except little dilatation of the central vein and slightly more sinusoidal spaces than control (Fig.4 E\&F). 

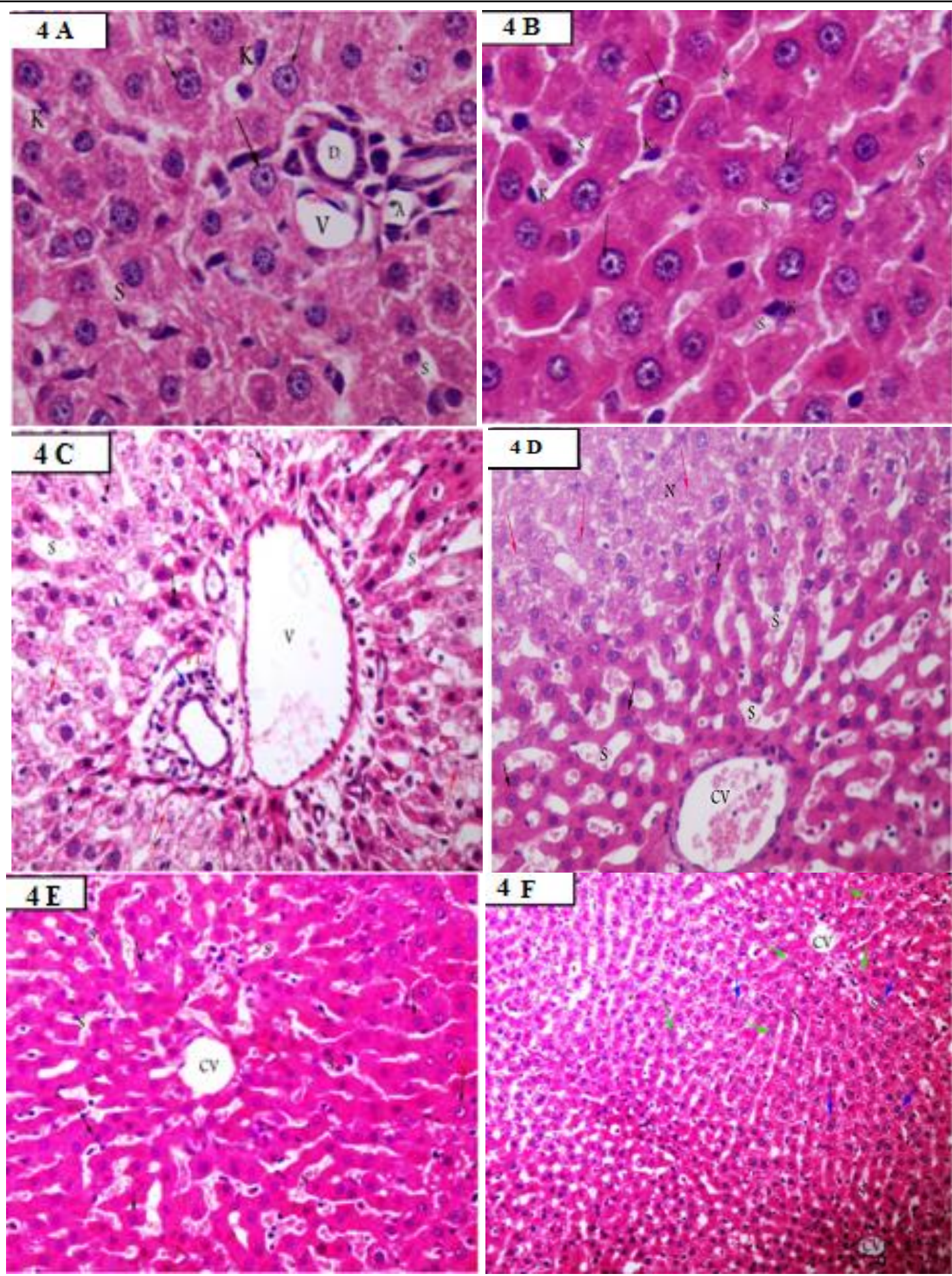

Fig (4): Showing liver tissues from control group (fig 4A,B), HFD group (4C,D) and Reversterol group (E,F) stained with $\mathrm{H} \& \mathrm{E}$ (400 X magnifications) 


\section{DISCUSSION}

Type 2 diabetes mellitus (DM-2) is a metabolic disorder, influenced by a variety of lifestyle factors including diet, stress, lack of physical activity and alcohol consumption. Current anti diabetic treatment strictly focuses on the management of glycaemia along with reduction of associated diabetic complications including organ damages $^{14}$.

This study focuses on therapeutic intervention that can reduce hyperglycemia as well as metabolic abnormalities with reduction of hepatic oxidative stress in the fructose- fed rats. Fructose is mainly consumed with added sugars. This hexose is essentially metabolized in splanchnic tissues where it is converted into glucose, glycogen, lactate and to a minor extent fatty acids ${ }^{20,21}$.

In this study, we evaluate the effect of resveratrol, a nutritional supplement on insulin resistance and hepatic oxidative stress in fructose-fed rats. High fructose intake over a long period is well known risk factor for diabetes and obesity ${ }^{22 .}$ We used a high fructose diet as animal model for the induction of insulin resistance, metabolic syndrome and oxidative stress.

Nakagawa et $\mathrm{al}^{23}$; and Reungiui et $\mathrm{al}^{24}$ have shown that long-term fructose feeding induces diabetes associated with insulin resistance and metabolic syndrome in experimental animals. ${ }^{(23,24)}$ Other previous studies showed that fructose consumption causes metabolic alterations in liver that leads to abnormalities including oxidative stress $^{25}$.

In the present study, fructose rich diet feeding for 8 weeks showed significant increase in fasting and postprandial blood glucose levels along with increased serum triglyceride, insulin levels and HOMA-IR. Administration of resveratrol reduced the increased blood glucose levels, insulin resistance along with serum triglyceride.

Laurene et $\mathbf{a l}^{26}$ and Chen et $\mathbf{a l}^{27}$ had stated that resveratrol administration increased insulin secretion from beta cells and it is possible that higher levels of insulin due to resveratrol might be responsible for improvement of insulin sensitivity.

Although there was no change in body weight gain in fructose-fed animals, resveratrol administration resulted in a significant reduction in body weight gain, which might also responsible for improved insulin sensitivity. Serum triglyceride, which may be also responsible for the increase in insulin resistance in fructose-fed rats was significantly reduced after resveratrol administration.

Increased serum NO levels have been reported in diabetic patients as well as fructose-fed diabetic rats. ${ }^{13}$ Increased NO levels can also induce oxidative damage through the formation of peroxynitrate ${ }^{28,29}$ 
In our study, serum NO level was significantly higher in fructose-fed rats compared to the control rats. Administration of resveratrol normalized the NO level in fructose-fed rats. The reduction of serum NO level might be due to reduction of oxidative stress in fructose-fed rats after resveratrol administration ${ }^{28 .}$

A key contributor to insulin resistance and the metabolic syndrome appears to be the abundance of TG perhaps in part due to high fructose intake, exceeding the storage capacity of adipose tissue and impairing adipocyte signaling. The end result is ectopic fat storage, accompanied by modified secretion of hormones and cytokines by adipose tissue and an inflammatory state, all of which cause damaging abnormalities in signaling within insulin-sensitive tissues ${ }^{22}$.

In this study serum MCP-1, RANTES and TNF- $\alpha$ level were significantly higher in fructose fed rats. Resveratrol administration significantly reduces these parameters. TNF$\alpha$ accelerates insulin resistance ${ }^{30}$ Experimental studies have shown that treatment with pro-inflammatory cytokines induces hypertriglyceridemia and insulin resistance. TNF- $\alpha$ down regulates the tyrosine kinase activity of the insulin receptor, thereby increases insulin resistance. ${ }^{31}$ The reduction of inflammation is an important target in the treatment of metabolic syndrome. Resveratrol has been shown to inhibit pro-inflammatory enzymes including cyclooxygenase, lipoxygenase and inducible nitric oxide synthase via activation of peroxisome proliferators-activated receptor gamma. In addition, phenolic compounds have been shown to inhibit phosphoinositide 3-kinases, tyrosine kinases, nuclear factorkappa $\mathrm{B}$ and the expression of endothelin$1 .{ }^{32}$

Both experimental and clinical studies indicate that oxidative stress plays a major role in the development and complications of type 2 diabetes $^{33}$. Free radicals are generated in diabetes by glucose oxidation. The oxidative stress may be amplified by diabetes-induced metabolic stress, tissue damage, and apoptosis, leading to increased free radical production and compromised free radical scavenger systems, which further exacerbate the oxidative stress. Oxidative stress can also lead to damage of cellular organelles, and development of insulin resistance. ${ }^{34}$ In our study, high fructose feeding increased oxidative stress as evidenced by significant elevation of TBARS level and reduction of vitamin $\mathrm{C}$ levels in the liver in comparison to control group. Resveratrol reduced hepatic TBARS and increased hepatic GSH and vitamin $\mathrm{C}$ levels in the fructose-fed liver. This beneficial antioxidant effect might be responsible for improved insulin sensitivity 
in fructose-fed rats after resveratrol administration.

Histopathological examination reveals the presence of inflammation, these changes were not observed when fructose-fed rats were treated with resveratrol. Kawasaki et $\mathrm{al}^{35}$ had reported the occurrence of inflammation and fatty liver in fructose feeding rat. Maher et al measured hepatic NRF2 protein level. Nuclear factor E2related factor 2 (NRF2) is a transcription factor important in the protection against any oxidative stress. During oxidative stress, NRF2 is released from sequestration in the cytoplasm and translocates to the nucleus. NRF2 binds antioxidant response elements (AREs) in the regulatory regions of target genes and activates transcription of several antioxidant enzymes ${ }^{36}$. Several NRF2 activators have already been developed for treating diseases involving oxidative stress ${ }^{34}$. Interestingly, NRF2 activators have also been shown to modulate insulin action ${ }^{37}$. Hyperglycemia-induced endothelial dysfunction, vascular complications and cardiomyocyte damage was prevented by NRF2 activation by reducing oxidative stress. Previous studies demonstrated that beneficial antioxidant effect of resveratrol was associated with increased nuclear translocation of NRF2 in fructose-fed liver. Increased nuclear NRF2 level might have a significant protective role against high fructose induced oxidative stress in liver, possibly through augmentation of hepatic antioxidant defense enzymes.

\section{CONCLUSION}

Resveratrol is a food supplement that causes hypoglycemia, hypotriglyceridemia and decreased insulin resistance. It has antioxidant and anti-inflammatory effects. These results support its utilization as a therapeutic tool that targets the hazards of metabolic syndrome. Further researches are needed to clarify the mechanistic role of this supplement in human diabetic patients.

\section{Acknowledgments}

We would like to gratefully acknowledge Assistant professor Mohamed Elsheref Pathology department for his effort and help.

Competing Interests: None

\section{REFERENCES}

1. Ilhan N., Kaman D. and IlhanN.,.The effect of resveratrol on biochemical changes in fructoseinduced insulin resistance, journal of Clinical and Experimental Investigations ; 2 (4) :339-46, 2011.

2. Bhatt J.K., Thomasb S. andNanjana M.J. Resveratrol supplementation improves glycemic control in type 2 diabetes mellitus, 
NutritionResearch,32 $537-41,20$ 12.

3. Burns J., Yakota T., Ashihara H., Lean M.E., Crozier A. Plant foods and herbal sources of resveratrol. J. Agric. Food Chem.; 50, 333740,2002 .

4. PervaizS.Resveratrol: from grapevines to mammalian biology. FASEB J; 17, 1975-85, 2003.

5. Hung L.M., Chen J.K., Huang S.S., Lee R.S., Su M.J. Cardioprotective effect of resveratrol, a natural antioxidant derived from grapes. Cardiovasc.Res.; 47, 549-55,2000.

6. Das S., Alagappan V.K., Bagchi D., Sharma H.S., Maulik N., Das D.K. Coordinated induction of iNOS-VEGF-KDR-eNOS after resveratrol consumption: a potential mechanism for resveratrol preconditioning of the heart.Vasc. Pharmacol.; 42, 281-9,2005.

7. Atten M.J., Attar B.M., Milson T., Holian O. Resveratrol-induced inactivation of human gastric adenocarcinoma cells through a protein kinase C-mediated mechanism. Biochem.Pharmacol.62, 1423-32, 2001.
8. El-MowafyA.M., Alkhalaf M. Resveratrol activates adenylylcyclase in human breast cancer cells: a novel, estrogen receptorindependent cytostatic mechanism. Carcinogenesis; 24, 869-73,2003.

9. de la LastraC.A.and Villegas I. Resveratrol as an antioxidant and pro-oxidant agent: mechanisms and clinical implications. Biochem.Soc. Trans.; 35, 1156-60, 2007.

10. Kopp P. Resveratrol, a phytoestrogen found in red wine. A possible explanation for the conundrum of the 'French paradox'?Eur. J. Endocrinol.; 138, 619-20, 1998.

11. Bertelli A.A. and Das D.K.,.Grapes, wines, resveratrol and heart health. J. Cardiovasc. Pharmacol.; 54, 468-76, 2009.

12. Bishayee A. Cancer prevention and treatment with resveratrol: from rodent studies to clinical trials. Cancer Prev. Res.;2, 409-18, 2009.

\section{Padiya R., Khatua T.N., Bagul} P.K., Kuncha M., Banerjee S.K. Garlic improves insulin sensitivity and associated metabolic syndromes in fructose fed rats. Nutrition and Metabolism;8:53-8,2011. 
14. Ates O., Cayli S.R., Yucel N., Altinoz E., Kocak A., Durak M.A. Central nervous system protection by resveratrol in streptozotocin induced diabetic rats. Journal of Clinical Neuroscience;14(3):25660, 2007.

15. Peter J. V., Meghan E. S., Lisa B.E. and Daniels D. Food Intake in Laboratory Rats Provided Standard and Fenbendazolesupplemented Diets J Am Assoc Lab Anim Sci. ; 47(6): 46-50, 2008.

16. Sojitra B., Bulani Y., Putcha U.K., Kanwal A., Gupta P., Kuncha M.

Nitric oxide synthase inhibition abrogates hydrogensulfide-induced cardioprotection in mice. Molecular and Cellular Biochemistry ; 360:619,2011

17. Okhawa H., Oohishi N., Yagi K. Assay for lipid peroxides in animal tissues by thiobarbituric acid reaction. Annals of Biochemistry; 95:351-8, 1979.

18. Banerjee S.K., Dinda A.K., Manchanda S.C., Maulik S.K. Chronic garlic admin-istration protects rat heart against oxidative stress induced by ischemic reperfusion injury. BMC Pharmacology; 9:1-9, 2002.
19. 19)Roe J.H. and Kuether C.A. Determination of ascorbic acid in whole blood and urine through the 2,4-dinitro phenylhydrazine derivative of dehydroascorbic acid. Journal of Biological Chemistry; 147:399-407,1942.

20. Tappy L. and Lee K.A. Metabolic effects of fructose and the worldwide increase in obesity. Physiological reviews ; 90:2346,2010.

21. Cade W.T. Diabetes-related microvascular and macrovascular diseases in the physical therapy setting. Physical Therapy; 88(11):1322-35, 2008.

22. Basciano H., Federico L., Adeli K. Fructose, insulin resistance, and metabolic dyslipidemia. NutrMetab; 2 (1): 5-8, 2005.

23. Nakagawa T., Hu H., Zharikov S., Tuttle K.R., Short R.A., Glushakova $\mathbf{O}$. A causal role for uric acid in fructose-induced metabolic syndrome.American Journal of Physiology; 290:625-31, 2006.

\section{Reungjui S., Roncal C.A., Mu W.,} Srinivas T.R., Sirivongs D., Johnson R.J. Thi-azide diuretics exacerbate fructose-induced 
metabolic syndrome. Journal of the American Society of Nephrology;18:2724-31, 2007 .

25. Abdelmalek M.F., Suzuki A., Guy C.,Unalp-Arida A., Colvin R., Johnson R.J. et al. Increased fructose consumption is associated with fibrosis severity in patients with nonalcoholic fatty liver disease. Hepatology; 51:1961-71, 2010.

\section{LaureneV., Thierry B., Laurianne} G., Domenico B., Pierre M. Resveratrol poten-tiates glucosestimulated insulin secretion in INS1e -cells and human islets through a SIRT1-dependent mechanism. Journal of Biological Chemistry; 286:6049-60, 2011.

27. Chen W.P., Chi T.C., Chuang L.M., Su M.J. Resveratrol enhances insulin secretion by blocking $\mathrm{K}$ (ATP) and $\mathrm{K}(\mathrm{V})$ channels of beta cells. European Journal of Pharmacology; 568:269-77,2007.

28. Mattapally S. and Banerjee S.K. Nitric oxide: redox balance, protein modification and therapeutic potential in cardiovascular system. IIOAB Journal; 2:29-38, 2011.

29. Pacher L., Beckman J.S., Liaudet L. Nitric oxide and peroxynitrite in health and disease. Physiological Reviews; 87:315-24, 2011.

30. Liu R.H., Mizuta M., Kurose T., Matsukura S. Early events involved in the development of insulin resistance in Zucker fatty rat. Int $\mathbf{J}$ ObesRelatMetabDisord; 26(3):318-26(2002).

31. Fernández-Veledo S., NietoVazquez I., Vila-Bedmar R. Molecular mechanisms involved in obesity-associated insulin resistance: therapeutically approach. Arch PhysiolBiochem; 115(4):22739(2009).

32. Milne J.C., Lambert P.D., Schenk S., et al. Small molecule activators of SIRT1 as therapeutics for the treatment of type 2 diabetes. Nature; 450(7170):712-6, 2007.

33. Giacco F. and Brownlee $M$. Oxidative stress and diabetic complications. Circulation Research; 107:1058-70, 2010.

\section{Yu Z.W., Li D., Ling W.H., Jin T.} Role of nuclear factor (erythroidderived 2)-like 2 in metabolic homeostasis and insulin action: a novel opportunity for diabetes treatment? World Journal of Diabetes; 3 (1): 19-28, 2012. 
35. Kawasaki T., Igarashi K., Koeda T., Sugimoto K., Nakagawa K., Hayashi S., et al. Rats fed fructoseenriched diets have characteristics of nonalcoholic hepatic steatosis. Journal of Nutrition; 139:2067-71, 2009.

36. Maher

J.M., Dieter

M.Z., Aleksunes

L.M., Slitt

A.L., Guo G., Tanaka Y. and Scheffer G.L. et al. Oxidative and electrophilic stress induces multidrug resistance-associated protein transporters via the nuclear factor-E2-related factor-2 transcriptionalpathway.Hepatology. ;46(5):1597-610, 2007.

37. Yu Z., Shao W., Chiang Y., Foltz W., Zhang Z., Ling W. et al. Oltipraz up regulates the nuclear factor (erythroid-derived 2)-like 2 (NRF2) antioxidant system and prevents insulin resistance and obesity induced by a high-fat diet in C57BL/6J mice. Diabetologia; 54:922-34, 2011. 


\section{المستخلص العربي}

هدف الاراسة:

متلازمة التمثيل الغذائي و الاكسدة تعد من أهم المضاعفات لمرض النوع الثنانى من داء السكري.يهدف هذا الى دراسة تأثثر ريسفيراترول وهو مكمل غذائى و يستخدم على نطاق واسع على حساسية الانسولين، وبعض نواحى الأيض و الاكسدة الكبدية في الفئران التي تغذي على تركيز عالى من الفركتوز. طرق الدراسة: - مالم

تم تقسيم الفئران إلى ب مجموعات · ( في كل مجموعة. المجمو عة الأولى(مجموعة التحكم) و تغذى على65٪ نشا الذرة، المجموعة الثانية تغذى على فركتوز عالى التركيز و المجموعة الثالثة تغذى على فركتوز عالى التركيزجنبا إلى جنب مع جر عة واحدة من 10ملغ /كغ / يوم من ريسفير اترول فمويا لمدة 8أسابيع

في نهاية الجدول الزمني للتغذية،وجد أرتفاع بمستوى السكر و الأنسولين مع مقاومة الأنسولين مع زيادة كبيرة في الدهون الثثلاثية ومستويات أكسيد النتريكو زيادة في كبدي حمض ثيو باربيتيوريك المادة التفاعليةبالكبدو انخفاض كبير في فيتامين سي في المجموعة الثانية مقارنة مع مجموعة التحكم ـ مع أعطاء ريسفير اترول لوحظ تحسن معلمات الأيض كما أظهرت تأثير ريسفير اترول فى تهدئة معلمات الاكسدةمثل البروتين الجاذب الكيميائي ا ورم نخر ومنظم تنشيط خلايا T T العادية . الخلاصة :إن نتائج الدر اسة الحالية تثير بقوة إلى أن مكملات ريسفير اترول يمكن أن تستخدم كأداة علاجية للحد من مخاطر متلازمة الأيض. 